KRISZTIÁN Béla

\title{
A tanuló felnőtt
}

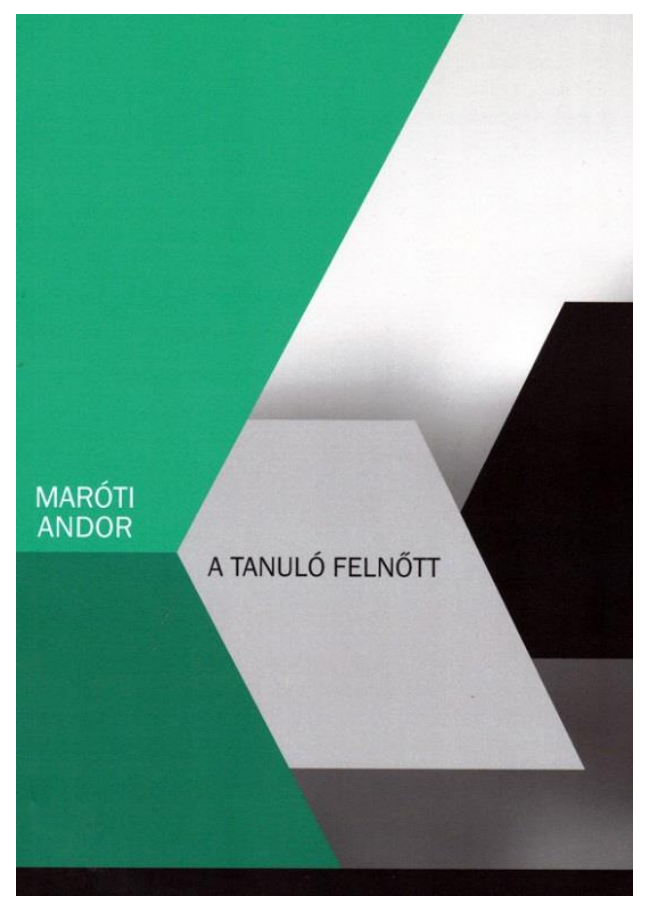

ELTE. Az Élethosszig Tartó Múvelődésért Alapitvány. Budapest. 2015.

Az ismeretszerzés klasszikus utja, az egymástól tanulásaz emberi közösség születésétől követhető. A tanulás/tanitás szerveződése évezredeken át befolyásolta az emberiség tudásának alakulását - egyben tükre az élethosszig tartó tanulás valóságának. A felnőttképzés elméletét atapasztalatok felhalmozódása, a munkamegosztás kiváltotta és kapcsolódó tudományok fejlődése, a társadalmi szervezettség alakulása - hogy csak ezeket emlitsük - a huszadik századrateremtették meg. Az ehhez kapcsolódó folyamatok sokrétűek, történelmi korszakokon átivelőek, aktuális és stratégiai jellegük következtében mindig a figyelem középpontjában állnak. E folyamatok elméletimegközelitésében ésgyakorlati hasznositásában évtizedek óta követhetjük Maróti Andor tudományos tevékenységét. Maróti Andor 1987-ben még $A z$ andragógia védelmében cimű cikkében foglalkozott a felnőttképzés addig kevéssé ismert területével (a Népmúvelés 1987. 3. száma), uj múve, $A$ tanuló felnőttma tudományos megalapozottsággal, igénnyel, kézzelfogható gyakorlatiassággal dolgozza fel a felnőttképzés és andragógia, a művelődés, önfejlesztés kérdéseit.

A mű stratégiai aktualitását erősiti, hogy megjelenése idején került nyilvánosságra a World Economic Forum jelentése, amely a következő évtizedek munkaerőhelyzetével foglalkozik. A meglepő változások a munkavállalók/felnőttek képzését is érintik majd, a változások dinamikája felnőttképzés dinamikáját is igényli.Az alkalmazásra készfelnőttképzés elmélete és gyakorlata az elmult évtizedekben a hazai és külföldi ismeretek kutatásával, közzéadásával 
igen kimeritően áll rendelkezésre. Ennek ellenére hatékonysága egyenetlen, ami miattfenntartásokkal kezelik.

A 19. századig a pedagógia az oktatási és nevelési folyamatban kizárólagos érvényű volt, fel sem merült, hogy a felnőttek tanításának eltérő szükségletei és sajátosságai lennének, mint a gyerekekének. Mint életkori meghatározás az andragógus kifejezés (androsz=férfi, felnőtt) előfordult, megalkotását egyesek Alexander Kapp (1833) német középiskolai tanárnak tulajdonítják. Több előfordulás mentén a diszciplína kibontakozását többek között Edward Lee Thorndike 1928-ban megjelent könyve, az Adult Learning is befolyásolta, aki a felnőttkori tanulást kutatta és irta le.

Az igazi fordulatot a felnőttképzésben a taylori tudományos vezetési elvek megjelenése majd a munkamegosztásból következő differenciált megközelités jelentette („a kopernikuszi fordulat" Maróti-92). A szervezetfejlesztés komplex igénye,Taylor, Fayol, Mayo, Gantt, Frank és Lillian Gilbreth,a menedzserizmus amerikai megalapozódása majd globális szétterjedése, az1940-es évekkutatásai meg a második világháboru tapasztalatai, az európai ujjáépités, átrendeződés, a BRICS országok - hogy csak ezeket emlitsük - rámutattak az emberi kapcsolatok fontosságára és arra, hogy a szociális tényezőknek milyen befolyása van az emberek motiválásában.

Taylortól kezdődően határozott és bővülő tartalommal és formában helyezték előtérbe az emberi (humán) erőforrás, azaz a ma széles körben elfogadott értelmezés a szervezet alkalmazottiösszességének megnevezésére. A foglalkoztatottak - elsősorban felnőttek szervezeti, emberi tulajdonságaira ia alapozó tanitási, motivációs rendszerének kialakitásában más tényezők is megjelentek. A felnőttképzésnek átfogó elmélete nincs, a pedagógiára támaszkodvaa tanulásközpontúságot figyelembe véve alkot praktikus elemeket adott helyzetekre. Nemzetközileg érzékelhető, hogy az európai (elsősorban német) megközelítésekben erőteljes a konkrét képzési orientáció, az angolszász felnőttképzésben a súlypont szinte teljesen eltolódott a (z egész életen át tartó) tanulás felé.

A különböző felnőttképzési, andragógiai megközelitések nagy ivenrajzolódnak, tükrei korszakuk és alkotójuk pedagógiai tudáskészletének, gazdasági és társadalmi összefüggés ismeretének, hasznosság- érdekeltségének.

Malcolm Knowles például a felnőtt-gyerek különbségére alapozvapedagógiai és andragógiai folyamatok között tesz különbséget.

Az andragógiaterületei a holland Michielse, és az ugyancsakholland T.T. ten Have felosztásábanaz általános és elméleti, az andragógia technológiai, az andragógia kutatási módszertan csoportositásban jelennek meg. Ide sorolódnak a szak-andragógiák, az andragógika, azalapelvek, eszmék, módszerek együttese, az agológia: a munka meg az andragológiatudománya, amely az andragógiát és az andragógikát tanulmányozza.

Pöggeler szerintafelnőttképzés szervezett forma, meghatározott intézményekhez kapcsolódik. A felnőttképzés integrálja a tanulási célokat, a kínálatot és a módszerválasztást a felnőttek élet- és munkatapasztalataival és e tapasztalatok értékelésével. Aképzést megfelelően kiképzett munkatársak végzik. Afelnőttképzés mindenki számárahozzáférhető. Afelnőttképzésben való részvétel önkéntes,a képzés a felnőttélet minden szakaszában lehetséges és szükséges. 
A magyar andragógia sorsának alakulása sokszinű folyamat. Durkó Mátyás évtizedes munkássága alapján a magyar gazdaság teljesitményhiányára utalva megállapitja, hogy „a munka hatékonyságának, a termelékenységnek a növelése elsődlegesen és végső konzekvenciáiban a dolgozók múveltsége, ezáltal a képzés, nevelés, s ennek részeként a felnőttnevelés felé mutat". Továbbá, „ennek megfelelően kell a permanens múvelődés és nevelés szellemében korszerűsíteni a pedagógiát, és kell az andragógiát szakágai integrált egységében szemlélni. Az iskolarendszerü felnőttoktatást párhuzamosan kell kiépíteni a közoktatás minden szintjén, formájában és szervesen be kell illeszteni a közoktatás rendszerébe".

Jost Reischmann,,andragógia-központú” elméleti rendszerébenandragógia a felnőttek élethosszig tartó ('lifelong') és az élet minden területére kiterjedő ('lifewide') tudománya. A felnőtt-tanulás két csoportja a/ a felnőttek intencionális (szándékos, célra irányuló) és nem intencionális (nem szándékos) tanulása.

Ma az andragógia rendszerében szerepel az iskolarendszerű felnőttoktatás, az emberi erőforráshoz kapcsolódóandragógia egyrészt a munkaerőpiachoz kapcsolódva másrészt arra a célra, hogyrendelkezésre álljon a szervezeti stratégiát támogató humán erőforrás, a szociális munka andragógiája, a kriminál andragógia,a tanácsadás andragógiája (mentor, tutor), hogy csak ezeket emlitsük, mert a felnőttképzés szükségletei uj területeket is létrehoznak.

A hazai andragógiaaz 1960-as évektől - részben a munkás- ésvezetőképzéstől, szervezetfejlesztéstől igényelt feladatok teljesitésével - szükséglettévált, amelyben a formák és tartalmak változatosságával jelenteszközt a felnőttképzés számára.

A múvelődés integráló szerepét hangsulyozó Maróti Andor korábbi irásai nyomán nagyivű koncentrált gondolati egységbe foglalta azt, amit ma elvárunk az andragógiától és a tanuló felnőtt alatt értünk. Az izléses kiállitásu munka arra koncentrál, , amit ma alapként elvárhatunk a kérdéssel foglalkozóktól.

Megállapitásai egy része ma már közhelynek számit, más-más formában megjelenő de azonos tartalmak innovativ megerősitései a felnőttképzéssel összefüggő tények tudatositásának. Fejezetei - a kérdés felvetésétől a rogersi tapasztalatokig - azt az andragógiai tudatosságot tükrözik, amellyel szerzőnka felnőtt tanulás/képzés hatékonyságát munkásságával eddig is erősitette.A fejezetekhezillesztett irodalom célirányos továbbgondolkodásra késztet.

Kiindulása a mindenkor hasznos célorientált változás/változtatás szükségessége, a Változnia kell a múvelődésnek az információs társadalomban? fejezet, amit részletezve fejt ki. Afelvilágositó attitüd jelentősége, Az élethosszig tartó tanulás problémái, A pedagógiától távolodó andragógia, $A$ tanuló felnőtt, $A$ funkcionális analfabétizmus, Az idősek tanulásáról és tanitásáról,a,,Kopernikuszifordulat”a felnőttek tanitásában, A résztvevő központuság, $A$ csoportmunka módszerei, Az önirányitó tanulásról, A távoktatásról, Felnőttképzés a posztmodern társadalomban, Rogers könyveit olvasvafejezetekben sűritve adja át mindazt, amit ma az aktualitáson tulmutatva a tanuló felnőtt érdekében szükségesnek látunk.

Maróti Andor komplex szemléletmódjavizsgálandónak tartja az felnőttképzésben előfeltételekhez kötött tudásformákat, ezek együttese vezethet csak az andragógia teljességéhez. Ujból figyelmeztet a pedagógia mint norma-és mint valóságtudomány andragógiában is értelmezhető voltára. A felnőttképzésben megjelenő képzési megoldások látszólag nem igényelnek teoretikus meggondolásokat. A felnőttképzés elméletének valamilyen halmaza természetesen kifejti a maga háttérhatását, de csak kivételesen nyujt 
közvetlen cselekvési utmutatást. Még kevésbé garantálja a távlataiban pozitiv következményeket.

A felnőttképzéssel foglalkozók döntéseiben ezért is játszik olyan nagy szerepet belső normarendszerük, felkészültségük és az, hogyan és milyen mélységben elemzik a felnőttek tanulását, csökkentve az elmélet és gyakorlat közti távolságot, növelve a képzés hatékonyságát (Maróti-202). 